Zeszyty Naukowe Szkoły Głównej Gospodarstwa Wiejskiego w Warszawie

Problemy Rolnictwa Światowego tom 18 (XXXIII), zeszyt 4, 2018: 284-294

DOI: 10.22630/PRS.2018.18.4.118

Jerzy Kopiński ${ }^{1}$

Instytut Uprawy Nawożenia i Gleboznawstwa - Państwowy Instytut Badawczy

w Puławach

\title{
Ocena zmian organizacyjno-produkcyjnych w polskim rolnictwie w kontekście wybranych oddziaływań środowiskowych*
}

\section{Assessment of Organizational and Production Changes in Polish Agriculture in the Context of Selected Environmental Impacts}

\begin{abstract}
Synopsis. W pracy dokonano oceny zmian organizacyjnych i produkcyjności w polskim rolnictwie w kontekście wybranych oddziaływań środowiskowych, tj. salda bilansu azotu brutto. Dla wskazania zachodzących tendencji porównywano zmiany pomiędzy okresem lat 2002-2004 a latami 2014-2016. Badania wykazały, że mimo różnokierunkowych zmian m.in. powierzchni poszczególnych roślin uprawnych i pogłowia gatunków zwierząt inwentarskich, kształtowanych głównie przez uwarunkowania ekonomiczne, presja środowiskowa ze strony prowadzonej produkcji rolniczej w Polsce uległa zmniejszeniu. Nastapiło to, w procesie intensyfikowania produkcji rolniczej przeciętnie w skali kraju. Zjawisko to świadczy o poprawie efektywności gospodarowania azotem w Polsce.
\end{abstract}

Słowa kluczowe: zmiany organizacyjno-produkcyjne, produkcja rolnicza, oddziaływanie środowiskowe

\begin{abstract}
The paper presents the assessment of organizational and productivity changes in Polish agriculture in the context of selected environmental impacts, i.e. the gross nitrogen balance. To indicate trends, changes between research from 2002-2004 and 2014-2016 were compared. Studies have shown that despite multi-directional changes in the area of particular crop plants and livestock husbandry animals, which have been shaped mainly by economic conditions, environmental pressure from agricultural production has decreased. This occurred despite the process of intensifying average agricultural production on a national scale. This phenomenon shows the improvement of nitrogen efficiency in Poland.
\end{abstract}

Key words: organizational-production changes, agricultural production, environmental impact

JEL Classification: Q15, Q51, Q56

\section{Wprowadzenie}

$\mathrm{Na}$ rolnictwo ze względu na jego specyfikę należy patrzeć szerzej, gdyż odpowiedzialne zarządzanie składnikami pokarmowymi (żywieniowymi, nawozowymi) jest niezwykle ważnym elementem biogospodarki. Rolnictwo jest jedną z niewielu dziedzin gospodarki, która w swojej istocie prowadzona jest w środowisku przyrodniczym i która

${ }^{1}$ dr hab., Zakład Systemów i Ekonomiki Produkcji Roślinnej IUNG - PIB, ul. Czartoryskich 8, 24-100 Puławy, e-mail: jkop@iung.pulawy.pl; https://orcid.org/0000-0002-2887-4143

* Opracowanie wykonano $w$ ramach zadania $n r 2.1$ w Programie Wieloletnim IUNG-PIB 
ma fundamentalne znaczenie dla bezpieczeństwa żywieniowego (żywnościowego, zdrowotnego) (Michalczyk, 2013; Mikuła, 2012), ekonomicznego poprzez utrzymanie konkurencyjności (produkcyjnej i ekonomicznej), a także bezpieczeństwa środowiskowego. Dlatego racjonalne gospodarowanie składnikami nawozowymi, w tym azotem, poprzez maksymalizację użyteczności działalności rolniczej, wpisuje się w podstawową funkcję celu, jakim jest wytwarzanie dóbr i osiąganie dochodów (Kopiński, 2018; Zegar, 2014). Fundamentalne i decydujące znaczenie mają tu relacje zachodzące pomiędzy przychodami a kosztami zaangażowanych czynników produkcji (Rembisz, 2010).

Ciagłe przemiany ekonomiczne i strukturalne, obecnie w dość znacznym stopniu kreowane przez ramy Wspólnej Polityki Rolnej (WPR), ale także przez czynniki zewnętrzne tj. WTO (World Trade Organization), rynki - surowcowe, produktowe i kapitałowe, czy obecne i przyszłe umowy międzynarodowe, embargo w handlu z Rosja, zniesienie ceł w handlu $\mathrm{z}$ Ukrainą, inicjują procesy dostosowawcze w rolnictwie do zmieniających się warunków gospodarowania. Jak podkreśla Krasowicz (2009), w Polsce już od lat 90. oddziaływanie uwarunkowań ekonomiczno-organizacyjnych na produkcję rolniczą oraz tempo i kierunki zachodzących zmian jest większe niż czynników przyrodniczych.

W ostatnich latach, ze względu na tendencję coraz większego rozwierania nożyc cen produktów rolnych i cen środków do produkcji rolnej (Józwiak, 2013), wzrost wartości produkcji jest na ogół kreowany przez wzrost wydajności (produkcyjności) ziemi oraz zwierząt. Jest on pochodnąwzrostu intensywności produkcji, m.in. poprzez wzrost nawożenia, ale także poprzez lepsze wykorzystanie tzw. pozanawozowych czynników produkcji. W tym kontekście ważnym pozostaje kontrola czy ocena potencjalnego oddziaływania zachodzących zmian w rolnictwie na środowisko (Hatfield i Karlen, 1994; Kopiński, 2017a). Ocenę taką umożliwia wykorzystanie metody bilansu azotu brutto, jako jednego z głównych biogenów, którego saldo jest podstawowym wskaźnikiem agrośrodowiskowym (Kopiński, 2017a; Kremer, 2013).

Celem pracy było dokonanie oceny zmian organizacyjnych i produkcyjności $\mathrm{w}$ polskim rolnictwie w ostatnich kilkunastu latach XXI wieku w kontekście wybranych oddziaływań środowiskowych.

\section{Metody badań}

Badania i analiza miały charakter kameralny. Obejmowały one perspektywę średniookresową lat 2002-2016. Podstawowe źródło informacji stanowiły dane statystyczne Głównego Urzędu Statystycznego (GUS) (Użytkowanie... 2002-2013; Środki... 20022017; Produkcja... 2003-2017; Ochrona... 2004-2017; Rocznik... 2005-2017; Zwierzęta... 2015-2017), Głównego Inspektoratu Ochrony Środowiska (GIOŚ) (Stan... 2014), Krajowego Ośrodka Bilansowania i Zarządzania Emisjami (KOBiZE) (Poland's... 2016) i wyniki badań własnych.

Analizą objęto zmiany struktury organizacji oraz wielkości produkcji roślinnej i zwierzęcej w Polsce, tj. powierzchni i zbiorów głównych grup roślin uprawnych oraz pogłowia zwierząt i produktów zwierzęcych. Ocenę odziaływań środowiskowych dokonano na podstawie zmian sald bilansu azotu brutto (GNB) (rys. 1), sporządzonego według metody zaproponowanej, wymaganej przez OECD i Eurostat (Kremer, 2013; Kopiński, 2017a). Zmiany analizowanych wskaźników zaprezentowano w formie tabelarycznej i graficznej. 
W celu wyeliminowania wpływu zmienności w latach, analizę podstawowych wskaźników oparto na średnich z 3 lat. Dla wskazania tendencji porównywano zmiany zachodzące pomiędzy okresem lat 2002-2004 a latami 2014-2016.

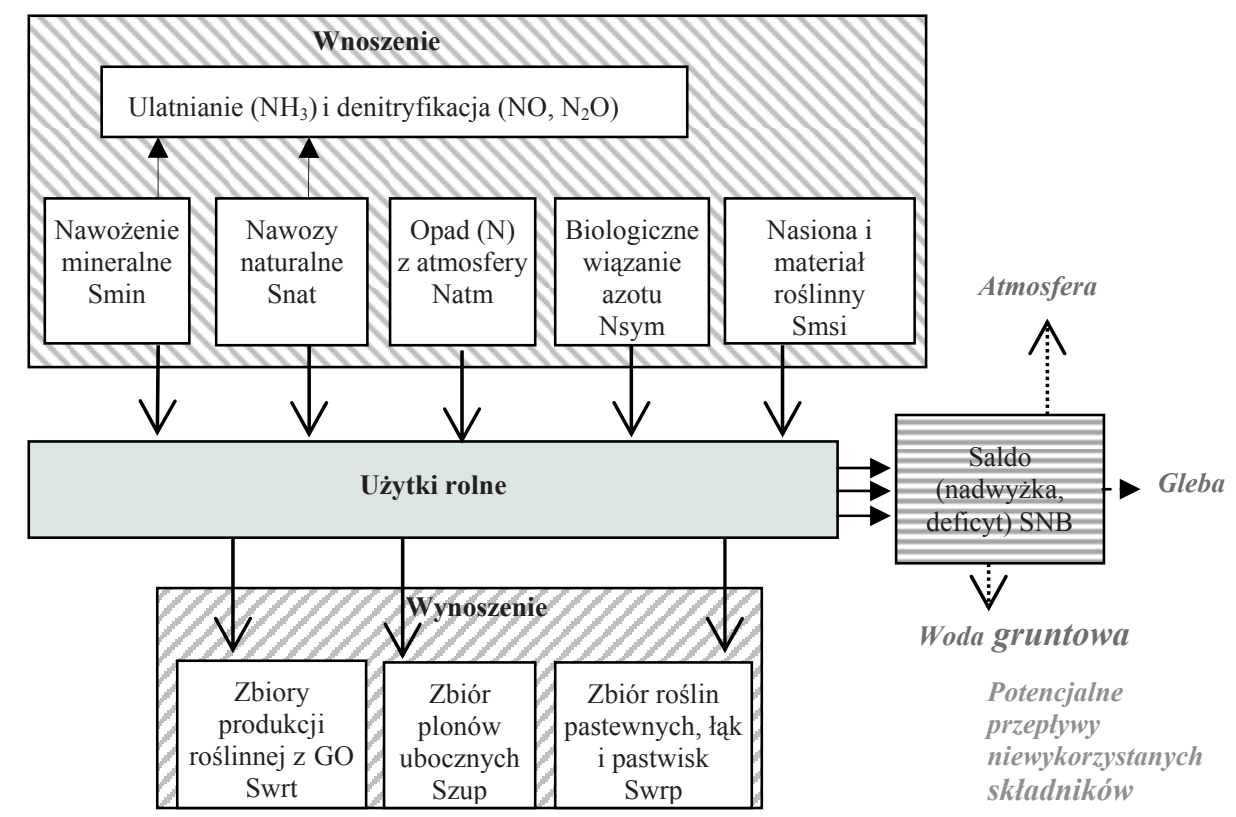

Rys. 1. Główne elementy bilansu (budżetu) azotu brutto (GNB)

Fig. 1. Main elements of gross nitrogen balances (budget) (GNB)

Źródło: opracowanie własne na podstawie: (Environmental... 2006).

\section{Wyniki badań i dyskusja}

Zmiany uwarunkowań rynkowych (ekonomicznych), w tym dotyczących rolnictwa, jakie miały miejsce w Polsce po wstappieniu do Wspólnoty Europejskiej (WE) (Wigier i in. 2011; Runowski, 2014; Matyka i Kopiński, 2016) wpłynęły na zmiany struktury zasiewów (rys. 2). W Polsce większość powierzchni gruntów ornych jest obsiewana (ok. 10,8 mln ha), a resztę (ok. 150 tys. ha) stanowią odłogi i ugory (Użytkowanie... 2002-2013). W strukturze zasiewów w ostatnich latach (2014-2016) nadal największy udział mają zboża (ok. 71\%), jednak udział ten w odniesieniu do lat 2002-2004 zmniejszył się o 4,6 p.p. Wśród zbóż systematycznie wzrasta w ostatnich latach udział powierzchni kukurydzy uprawianej na ziarno, co wiąże się z poprawą opłacalności i warunków klimatycznych dla jej produkcji (Matyka i Kopiński, 2016). W analizowanych latach systematycznie i znacząco, bo dwukrotnie, wzrastał udział uprawy rzepaku i rzepiku, zajmujących obecnie ok. 9\% powierzchni zasiewów. Podobna tendencja dotyczyła uprawy roślin strączkowych na nasiona i pastewnych $\mathrm{w}$ uprawie polowej. Natomiast, dość znacznie i systematycznie, maleje udział ziemniaka (obecnie poniżej 3\%), a w ostatnich latach również buraka 
cukrowego (1,8\%), którego znaczenie będzie się dalej zmniejszać w związku z przewidywaną liberalizacją rynku cukru w Europie (Szajner, 2017).

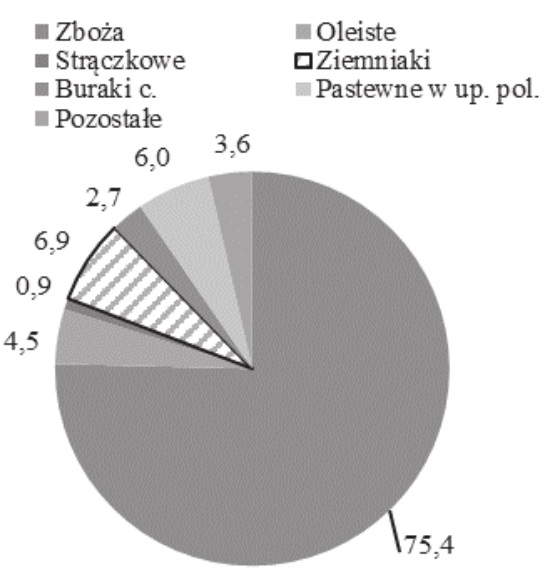

Lata 2002-2004

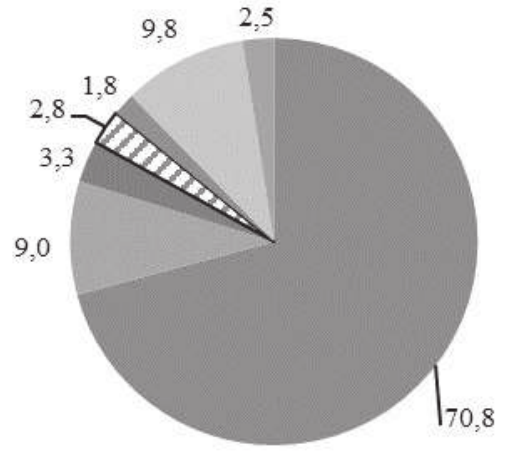

Lata 2014-2016

Rys. 2. Zmiany struktury zasiewów w Polsce pomiędzy latami 2002-2004 a okresem lat 2014-2016 (\%)

Fig. 2. Changes in the structure of sown area in Poland between 2002-2004 and 2014-2016 (\%)

Źródło: opracowanie własne na podstawie danych GUS: (Produkcja..., 2003-2017).

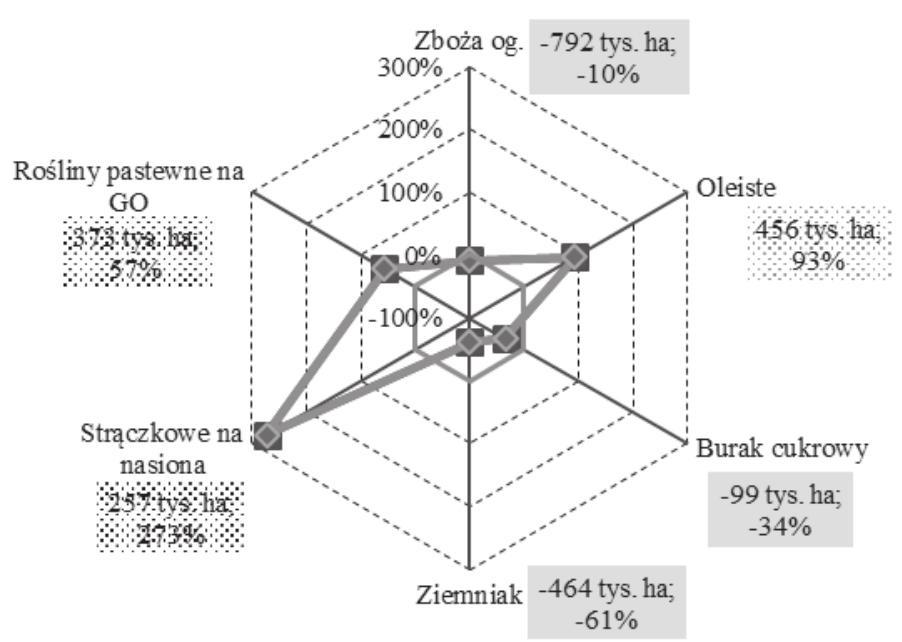

Rys. 3. Zmiany (różnica) powierzchni głównych grup roślin uprawnych w Polsce pomiędzy latami 2002-2004 a okresem lat 2014-2016 (tys. ha i \%)

Fig. 3. Changes (difference) in the area of the main groups of crop plants in Poland between 2002-2004 and $2014-$ 2016 (thous. ha and \%)

Źródło: opracowanie własne na podstawie danych GUS: (Produkcja..., 2003-2017). 
Pomiędzy latami 2002-2004 a okresem lat 2014-2016 powierzchnia uprawy zbóż w Polsce zmniejszyła się o ok. 790 tys. ha, buraka cukrowego o ok. 100 tys. ha, a ziemniaka o ok. 460 tys. ha (rys. 3). W tym czasie o ok. 450 tys. ha zwiększyła się powierzchni uprawy rzepaku i rzepiku, a także nastąpił wyraźny wzrost udziału powierzchni roślin strączkowych na nasiona (bobowatych grubonasiennych) i pastewnych uprawianych na gruntach ornych (GO).

Tabela 1. Zużycie azotu (N) w mineralnych i organicznych* nawozach azotowych w Polsce w latach 2002-2016 Table 1. Nitrogen $(\mathrm{N})$ consumption in mineral and organic nitrogen fertilizers in Poland in 2002-2016

\begin{tabular}{l|ccccc}
\hline \multicolumn{1}{c|}{ Zużycie } & $2002-2004$ & $2005-2007$ & $2008-2010$ & $2011-2013$ & $2014-216$ \\
\hline tys. t & 856,7 & 986,4 & 1093,1 & 1133,8 & 1052,9 \\
$\mathrm{~kg} \cdot \mathrm{ha}^{-1} \mathrm{UR} \mathrm{w} \mathrm{dk}$ & 52,6 & 62,5 & 71,6 & 78,4 & 73,5 \\
\hline
\end{tabular}

* - z wyjątkiem nawozów naturalnych pochodzenia zwierzęcego

Źródło: opracowanie własne na podstawie danych GUS: (Środki..., 2002-2017).

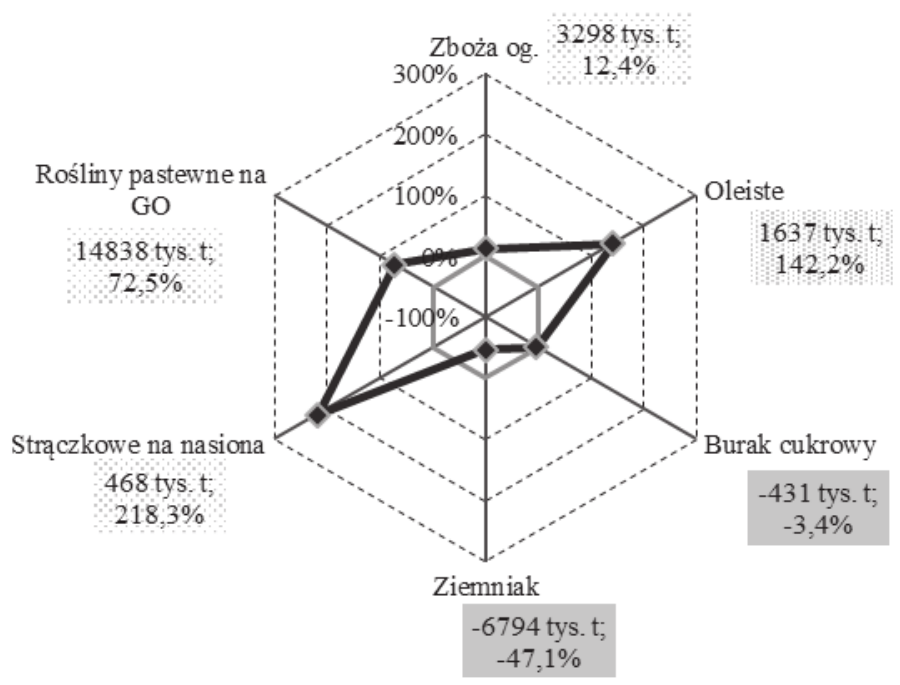

Rys. 4. Zmiany zbiorów głównych grup roślin na gruntach ornych GO w Polsce pomiędzy latami 2002-2004 a okresem lat 2014-2016 (tys. $\mathrm{i} \%$ )

Fig. 4. Changes in the production of main groups of plants on arable land (ArL) in Poland between 2002-2004 and 2014-2016 (thous. $t$ and \%)

Źródło: opracowanie własne na podstawie danych GUS: (Produkcja..., 2003-2017).

Z punktu widzenia celów ekonomicznych, ale i środowiskowych istotne znaczenie mają zmiany wielkości produkcji poszczególnych ziemiopłodów. Są one pochodną nie tylko zmian powierzchni, ale także produkcyjności (plonowania) poszczególnych upraw roślin. Jak twierdzi Kopiński i Matyka (2016), zmniejszaniu się powierzchni gruntów ornych towarzyszy zwiększanie się intensywności produkcji (mierzonej m.in. wzrostem stosowanych dawek azotu $\mathrm{w}$ produkcji roślinnej). W Polsce $\mathrm{w}$ analizowanym okresie 
jednostkowe zużycie azotu wzrosło o ponad $20 \mathrm{~kg} \cdot \mathrm{ha}-1 \mathrm{UR}$ w dk (tab. 1). Oczywiście nie bez znaczenia jest także lepsze wykorzystanie tzw. pozanawozowych czynników wzrostu produkcji poprzez wdrażanie postępu genetyczno-hodowlanego, nowoczesnych technik uprawy, itp. (Smagacz, 2016). Z analizy zmian zbiorów głównych roślin uprawnych (rys. 4) wynika, że wyraźnemu zmniejszeniu, bo o $47 \%$, uległy zbiory ziemniaka, podczas gdy zbiory buraka cukrowego zmniejszyły się tylko o ok. $3 \%$. Natomiast wzrosły w Polsce zbiory pozostałych grup roślin, w tym także mimo spadku powierzchni zbiory zbóż (o ok. $12 \%)$. Należy także dodać, że tempo wzrostu plonowania roślin uprawnych w Polsce jest zbliżone do dynamiki zmian plonowania pszenicy ogółem, ale jest ciągle mniejsze niż przeciętne dla krajów UE-27 (Matyka, 2014). Z punktu widzenia potencjalnych konsekwencji środowiskowych wysokie plonowanie roślin rolniczych musi jednak być powiązane z optymalizacją wykorzystania podstawowych czynników plonotwórczych, tj. potencjału genetycznego, warunków glebowych i klimatycznych, poziomu agrotechniki oraz organizacji produkcji (Marques da Silva i in. 2012).

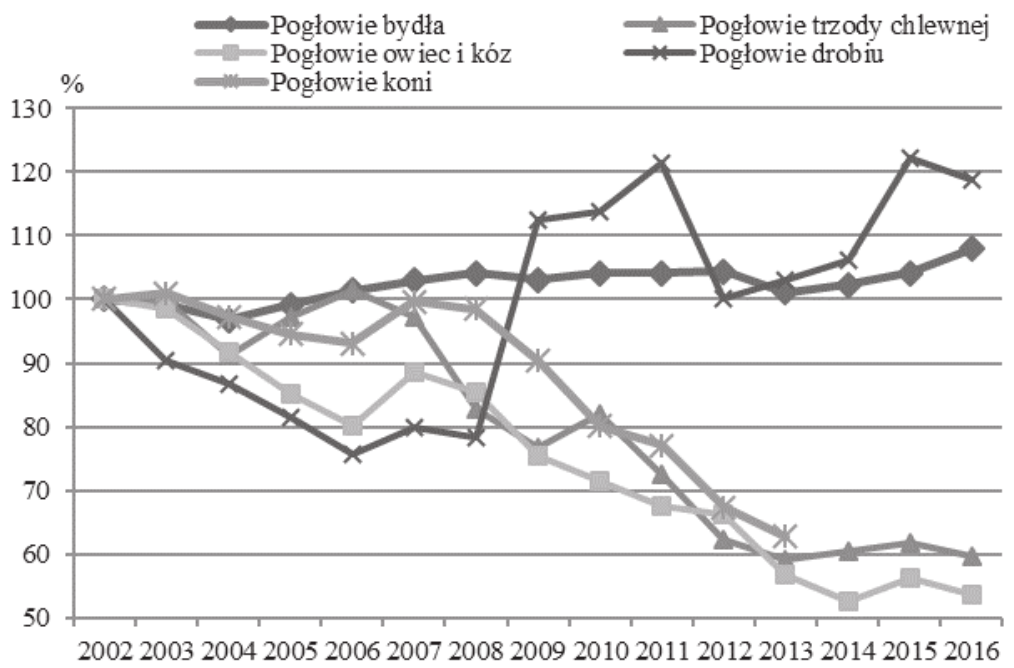

Rys. 5. Zmiany pogłowia zwierząt inwentarskich (\%) w Polsce w latach 2002-2016. Rok $2002=100$

Fig. 5. Changes in the livestock (\%) from 2002-2016. 2002 year $=100$

Źródło: opracowanie własne na podstawie danych GUS: (Użytkowanie..., 2002-2013; Zwierzęta..., 2015-2017).

Niewątpliwy wpływ na zmiany zachodzące $\mathrm{w}$ produkcji zwierzęcej w Polsce w ostatnich kilkunastu latach ma członkostwo we Wspólnocie Europejskiej (WE) i następnie wprowadzane w tym okresie regulacje prawne (Kopiński, 2017a). Innym istotnym czynnikiem są także uwarunkowania zewnętrzne (polityczno-rynkowe), kształtujące konkurencyjność sektora rolno-spożywczego (Nosecka, 2012), zmiany warunków pogodowych, klimatycznych, a także epidemiologicznych, oddziaływujących na kształtowanie się relacji cen pasz i produktów zwierzęcych. Główne produkty produkcji zwierzęcej, tj. mleko, żywiec drobiowy i wieprzowy, są w Polsce jednocześnie dominującymi kierunkami towarowej produkcji rolniczej, mimo istotnych zmian pogłowia zwierząt inwentarskich. Od kilkunastu lat obserwujemy dynamiczny spadek, poza bydłem i drobiem, pogłowia wielu gatunków zwierząt (rys. 5). Szczególnie niepokojąco wygląda 
obecna sytuacja w chowie trzody chlewnej, w znacznym stopniu wynikająca ze skutków powodowanych przez afrykański pomór świń (ASF) (Zagrożenia..., 2015). Waga zmian zachodzących w produkcji zwierzęcej, z punktu oddziaływań środowiskowych, jest o tyle ważna gdyż rzutuje także na zmiany puli nawozów naturalnych, drugiego obok nawożenia mineralnego, bardzo ważnego źródła dopływu azotu (Kopiński, 2017a). Zmiany dotyczące zużycia azotu pochodzącego z produkcji zwierzęcej, jako jej „produktu ubocznego”, są pochodną zamian wielkości pogłowia i struktury zwierząt gospodarskich. Pomiędzy latami 2002-2004 a 2014-2016 zwiększyła się ilość azotu, którego źródłem był chów bydła i drobiu (razem o ok. 19 tys. t N), przy czym znacząco spadła się ilość azotu pochodzącego z chowu trzody chlewnej (o 56 tys. t N) (rys. 6). O $16 \%$ zmniejszyła się ilość azotu emitowana w związkach gazowych do atmosfery.

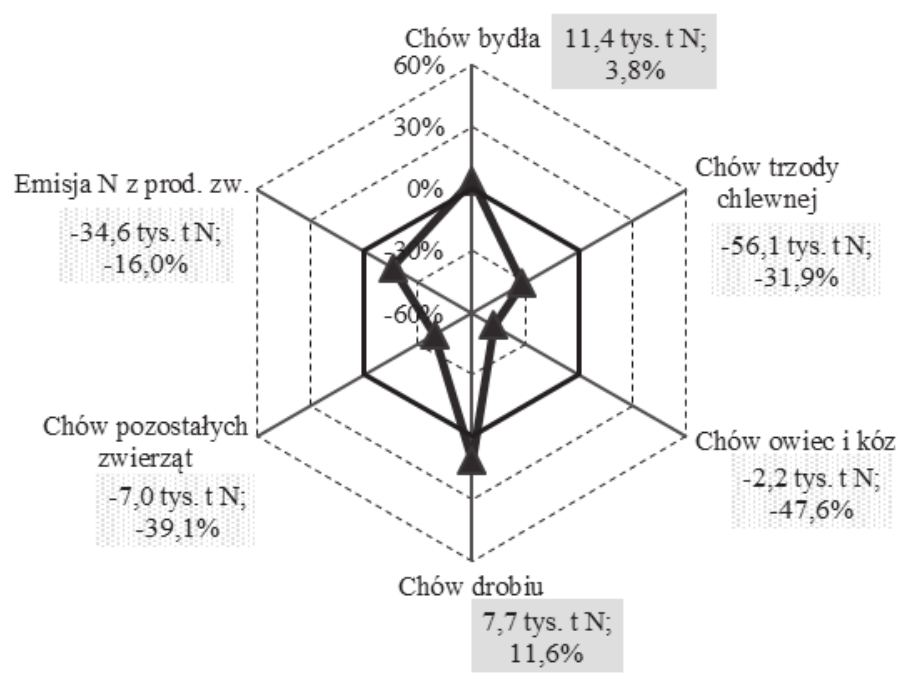

Rys. 6. Zmiany ilościowe azotu z produkcji zwierzęcej (tys. t N, \%) wg źródeł pochodzenia w Polsce pomiędzy latami 2002-2004 a okresem lat 2014-2016

Fig. 6. Quantitative changes of nitrogen from animal production (thous. $\mathrm{t}$ ) by sources of origin in Poland between 2002-2004 and 2014-2016

Źródło: opracowanie własne na podstawie danych: GUS (Użytkowanie..., 2002-2013; Zwierzęta..., 2015-2017) i KOBiZE (Poland's..., 2016).

Zmiany ilościowe różnych źródeł przychodu i rozchodu azotu brutto w ostatnich 14 latach przedstawione na rysunku 7 są obrazem sytuacji i zmian uwarunkowań prowadzenia produkcji rolniczej w Polsce, w aspekcie gospodarki nawozowej azotem. Ocena i analiza umożliwia określenie charakteru, sposobu prowadzonej produkcji rolniczej (intensyfikacja, ekstensyfikacja) (Kopiński, 2018). Z rysunku 7 wynika, że w analizowanym okresie zwiększyło się w Polsce, chociaż w różnym stopniu bo od 4 do $18 \%$, wynoszenie azotu W zbiorach roślin z powierzchni użytkowanej rolniczo. Korzystnie, z punktu widzenia środowiskowego i ekonomicznego (wyższa efektywność), pozytywnie należy ocenić zmniejszenie się dopływu azotu do systemu produkcji rolniczej pochodzącego z nawozów naturalnych (razem z emisja), z depozytu atmosferycznego i w materiału siewnego 
i sadzeniowego. Pozytywną zmianą jest także wzrost ilości azotu wiązanego $\mathrm{z}$ atmosfery przez bakterie symbiotyczne w uprawach roślin bobowatych, co jednak należy uznać za proces pozytywny. Najbardziej, bo o 187 tys. t N, wzrosła ilość dostarczane w nawozach mineralnych.

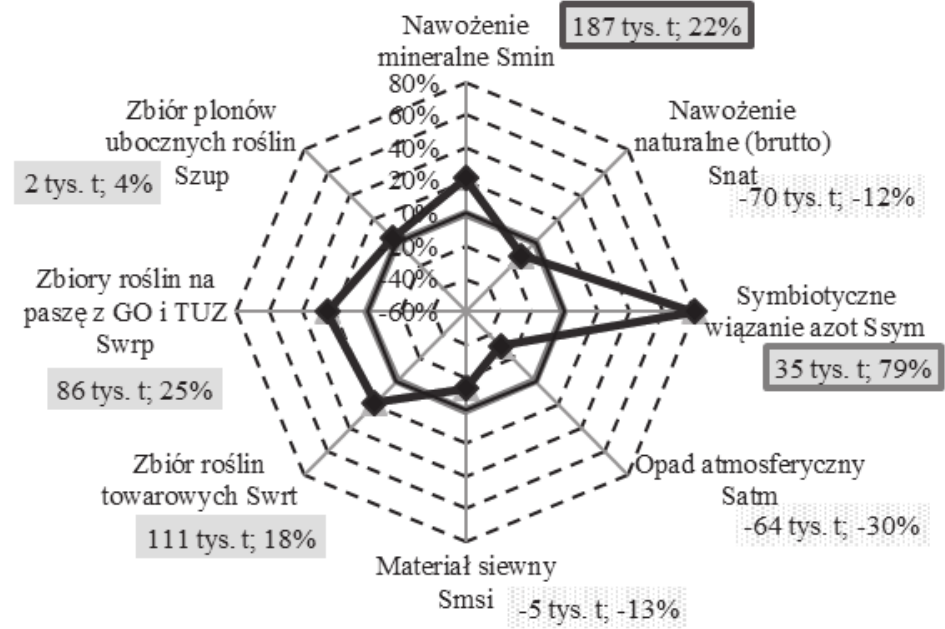

Rys. 7. Zmiany ilościowe w elementach składowych bilansu azotu brutto (tys. t N, \%) w Polsce pomiędzy latami 2002-2004 a okresem lat 2014-2016

Fig. 7. Quantitative changes in components of the gross nitrogen balance (thous. t N,\%) in Poland between 20022004 and 2014-2016

Źródło: opracowanie własne na podstawie danych: GUS, KOBiZE (Poland’s... 2016) i IOŚ uzyskanych w ramach Państwowego Monitoringu Środowiska (Stan..., 2014).

$\mathrm{Z}$ równania regresji wielorakiej standaryzowanej zamieszczonego poniżej wynika, że wielkość salda bilansu azotu brutto jest w zasadniczy sposób uzależniona od wnoszenia azotu z nawozami mineralnymi. Po stronie rozchodowej największy wpływ na wielkość końcową salda bilansu $\mathrm{N}$ brutto ma wynoszenie tego składnika ze zbiorami roślin towarowych. Analizę statystyczną wykonano za pomocą programu Statistica w oparciu o dane bilansu azotu brutto w okresie lat 2002-2016. Łączna ilość zmiennych każdej badanej cechy wynosiła 240.

$$
y=28,1+1,06 x_{1}+0,62 x_{2}-0,84 x_{3}-0,64 x_{4} \quad r^{2}=0,98\left(p_{0,05}\right)
$$

gdzie:

y (SNB) - saldo bilansu N ( $\mathrm{kg}^{-h^{-1}} \mathrm{UR}$ w dk),

$\mathrm{x}_{1}(\mathrm{Smin})$ - wnoszenie $\mathrm{z}$ nawozami mineralnymi $\left(\mathrm{kg} \cdot \mathrm{ha}^{-1} \mathrm{UR} \mathrm{w} \mathrm{dk}\right)$,

$\mathrm{x}_{2}$ (Snat) - wnoszenie z nawozami naturalnymi $\left(\mathrm{kg} \cdot \mathrm{ha}^{-1} \mathrm{UR} \mathrm{w} \mathrm{dk}\right)$,

$\mathrm{x}_{3}$ (Swrt) - wynoszenie ze zbiorami roślin towarowych $\left(\mathrm{kg} \cdot \mathrm{ha}^{-1} \mathrm{UR} \mathrm{w} \mathrm{dk}\right)$,

$\mathrm{x}_{4}$ (Szup) - wynoszenie ze zbiorami roślin pastewnych $\left(\mathrm{kg} \cdot \mathrm{ha}^{-1} \mathrm{UR} \mathrm{w} \mathrm{dk}\right)$,

$\mathrm{r}^{2}$ - wskaźnik determinacji. 


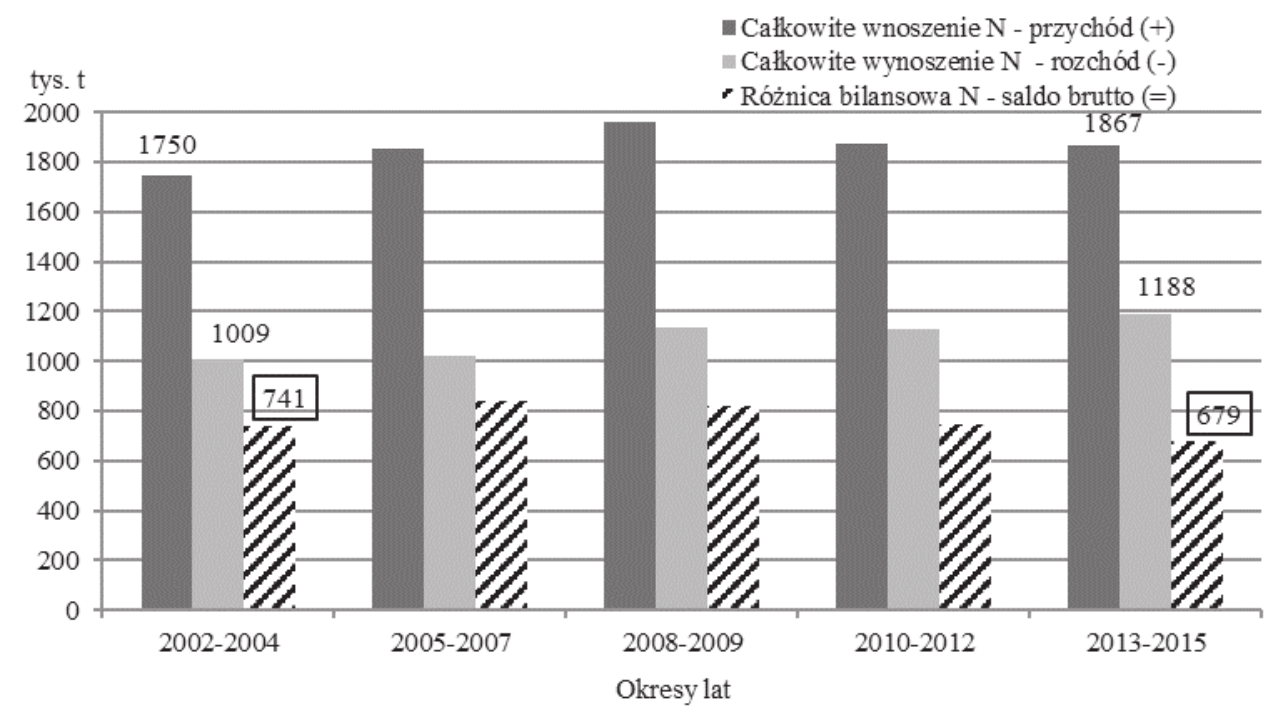

Rys. 8. Wyniki bilansu azotu brutto dla Polski (tys. t N) w okresach lat 2002-2016

Fig. 8. The results of the gross nitrogen balance for Poland (thous. $\mathrm{t} N$ ) in 2002-2016

Źródło: opracowanie własne na podstawie danych: GUS, KOBiZE (Poland’s... 2016) i IOŚ uzyskanych w ramach Państwowego Monitoringu Środowiska (Stan... 2014).

Efektem zmian ilościowych i strukturalnych poszczególnych źródeł obu stron bilansu azotu brutto jest wysokość salda (rys. 8). Zmiany struktury i wielkości produkcji zachodzące $\mathrm{w}$ ostatnich kilkunastu latach w produkcji rolniczej Polski, w kontekście odziaływań środowiskowych ze strony azotu, należy ogólnie ocenić pozytywnie. Mimo wzrostu całkowitej ilości wnoszonego azotu, pomiędzy latami 2002-2004 a 2014-2016 o ok. 117 tys. t, o wiele więcej wzrosło także jego wynoszenie (o 179 tys. t). W rezultacie saldo bilansu azotu brutto w Polsce uległo zmniejszeniu pomiędzy analizowanymi okresami o 62 tys. t N. Wynika to z poprawy efektywności wykorzystania azotu w Polsce (Kopiński, 2017b). Należy zatem stwierdzić, że obserwowany w Polsce, w latach 20022016, wzrost intensywności produkcji rolniczej i produktywności użytków rolnych, mierzonej wielkością obrotu azotem, nie prowadził do pogorszenia parametrów stanu środowiska. Jednak ocena ta dotyczy przeciętnych warunków dla kraju, gdyż już na poziomie województw zauważa się bardzo duże pod tym względem zróżnicowanie regionalne (Kopiński 2017a; 2018).

\section{Podsumowanie}

Przeprowadzona analiza zmian organizacyjnych i produkcyjnych w polskim rolnictwie w latach 2002-2016, ocenianych przez pryzmat zmian poszczególnych elementów składowych i wyników bilansu (budżetu) azotu brutto, wskazuje na znaczenie i rolę tej metody wskaźnikowej w pośredniej ocenie wywieranej presji środowiskowej wskutek 
gospodarowania tym składnikiem. Wynika z niej, że mimo różnokierunkowych zmian powierzchni uprawy roślin i pogłowia zwierząt inwentarskich, kształtowanych głównie przez uwarunkowania ekonomiczne, ale także przyrodnicze, presja środowiskowa ze strony prowadzonej produkcji rolniczej uległa zmniejszeniu. Wymiernym tego efektem jest wielkość aktualnego całkowitego salda bilansu azotu brutto w Polsce, które mimo wahań obecnie jest mniejsze o ok. 62 tys. t N niż w latach 2002-2004. Pozytywnie należy przyjąć, że do zmniejszenia siły oddziaływań środowiskowych doszło mimo widocznego procesu intensyfikowania produkcji rolniczej przeciętnie w skali kraju. W analizowanym okresie nastąpiło bowiem zwiększenie wielkości obrotu azotem w produkcji rolniczej, jednak tempo wzrostu wynoszenia azotu w zbiorach roślin uprawnych było zdecydowanie wyższe niż wzrost jego przychodu, generowany głównie przez zwiększające się zużycie azotu w nawozach mineralnych. Świadczy to o poprawie efektywności gospodarowania tym składnikiem w Polsce.

Analiza zmian bilansu azotu brutto na przestrzeni wielu lat umożliwia śledzenie kierunków, trendów przeobrażeń strukturalnych i organizacyjno-produkcyjnych zachodzących w polskim rolnictwie, dostarczając cennych informacji umożliwiających podejmowanie racjonalnych decyzji. Poza konsekwencjami środowiskowymi mogą one mieć także określone skutki ekonomiczne.

\section{Literatura}

Environmental indicators for agriculture (2006). OECD Publication Service, Paris, vol. 4, Chapter 3.

Hatfield, J. L., Karlen, D. L (1994). Sustainable Agriculture Systems. Lewis Publisher, Florida.

Józwiak, W. (2013). Warunki gospodarowania oraz zmiany zachodzące w rolnictwie w latach 1989-2010 (The conditions of management and changes occurring in agriculture in 1989-2010). W: Zmiany zachodzące w gospodarstwach rolnych w latach 2002-2010. PSR 2010. Wyd. GUS (red.) W. Józwiak, W. Ziętara. Warszawa, 7-23.

Kopiński, J. (2017a). Bilans azotu brutto - agrośrodowiskowy wskaźnik oddziaływania rolnictwa na środowisko. Opis metodyki, omówienie wyników bilansu na poziomie NUTS-0, NUTS-2 (Gross nitrogen balances (budget) - agrienvironmental indicators of changes of agricultural production. Methodology and the results of balances on the level NUTS-0 (Poland), NUTS-2 (voivodeships)). Wyd. IUNG-PIB Monografie $i$ rozprawy naukowe, Puławy, 55.

Kopiński, J. (2017b). Ocena zmian efektywności wykorzystania azotu w produkcji rolniczej Polski (Evaluation of changes in the efficiency of nitrogen utilization in agricultural production of Poland). Roczniki Naukowe SERIA, 19(1), 85-91.

Kopiński, J. (2018). Tendencje zmian intensywności gospodarowania azotem w regionach Polski (Tendencies of changing intensity of nitrogen management in the Polish regions). Roczniki Naukowe SERiA, 20(1), 81-87.

Krasowicz, S. (2009). Regionalne zróżnicowanie zmian w rolnictwie polskim (Regional diversity of changes in Polish agriculture). Studia i Raporty IUNG-PIB, 2009, 15, 9-36.

Kremer, A. M. (2013). Nutrient Budgets EU-27, Norway, Switzerland. Methodology and Handbook. Eurostat/OECD. EC Eurostat, ver. 1.02, Luxembourg, date: 17/05/2013. s. 112

Matyka, M. (2014). Plonowanie wybranych gatunków roślin uprawnych w Polsce, Niemczech i 27 krajach Unii Europejskiej w latach 1961-2012 (Yielding of selected agricultural crops in Poland, Germany and 27 countries of European Union in the years 1961-2012). Roczniki Naukowe SERiA, 16(3), 183-187.

Matyka, M., Kopiński, J. (2016). Tendencje zmian w produkcji roślinnej w Polsce w latach 2000-2014 (Trends in changes in plant production in Poland in 2000-2014 years). Monografie PW IERiGŻ-PIB, R-39, 11-31.

Margues da Silva, J. R., Rebollo, F. J., Sousa, A., Mesquita, P. (2012). Yield potential probability maps using the Rasch model. Biosystems Engineering, 111, 369-380.

Michalczyk, J. (2013). Główne przesłanki bezpieczeństwa żywnościowego Polski i próba jego pomiaru (Main determinants of Poland's food security and an attempt of its measuring). Prace Naukowe UE we Wrocławiu, $315,577-591$ 
Mikuła. A. (2012). Bezpieczeństwo żywnościowe Polski (Food security in Poland). Rocznik Naukowe Rolnictwa i Rozwoju Obszarów Wiejskich, 99(4), 39-48.

Nosecka, B. (red.) (2012). Czynniki konkurencyjności sektora rolno-spożywczego we współczesnym świecie (Factors of competitiveness of the agri-food sector in the modern World). Wyd. IERiGŻ-PIB (PW 20112014), Warszawa, 54.

Ochrona Środowiska 2016 (Envirnomental). (2004-2017). Wyd. GUS, Warszawa.

Poland's National Inventory Reports 2016, (2016). Wyd. IOŚ-PIB, KOBiZE, Warszawa.

Produkcja upraw rolnych i ogrodniczych w 2002...2016 roku (Production of agricultural and horticultural crops in 20002...2016), (2003-2017). Wyd. GUS, Warszawa.

Rembisz, W. (2010). Kwestie efektywności, cen i dochodów producentów rolnych (Productivity, prices and farm producers' incomes issues). Zeszyty Naukowe UE w Poznaniu, 150, 289-302.

Rocznik Statystyczny Rolnictwa (Statistical Yearbook of Agriculture). (2005-2017). Wyd. GUS, Warszawa.

Runowski, H. (2014). Ekonomika rolnictwa - przemiany w gospodarstwach rolnych (The economics of agriculture - changes in farms). W: Rolnictwo, gospodarka żywnościowa, obszary wiejskie - 10 lat w Unii Europejskiej. Wyd. SGGW (red.) N. Drejerska, Warszawa, 31-48.

Smagacz, J. (2016). Konsekwencje organizacyjne i środowiskowe różnych systemów uprawy roli (Organizational and environmental consequences of different tillage systems). Studia i Raporty IUNG-PIB, 47(1), 71-85.

Stan środowiska w Polsce. Raport 2014 (The state of the environment in Poland. Report 2014). (2014). Biblioteka Monitoringu Środowiska, Warszawa oraz dane GIOŚ 2017 niepublikowane.

Szajner, P. (2017). Strategiczne aspekty rozwoju sektora cukrowniczego w Polsce po reformie regulacji rynkowych w 2017 r. (Strategic aspects of the development of the sugar sector in Poland after the reform of market regulation in 2017). Mat. Konf. IERiGŻ-PIB, Licheń, 19-21 Czerwiec 2017.

Środki produkcji w rolnictwie w roku gospodarczym 2001/2002...2014/2015 (Means of production in agriculture). (2002-2017). Wyd. GUS, Warszawa.

Użytkowanie gruntów, powierzchnia zasiewów i pogłowie zwierząt gospodarskich w 2002, .. 2013 roku (Land use and sown area in 2002...2013). (2002-2013). Wyd. GUS, Warszawa.

Wigier, M. (red.). (2011). Analiza efektów realizacji polityki rolnej wobec rolnictwa i obszarów wiejskich (Analysis of the effects of agricultural policy implementation on agriculture and rural areas). Wyd. IERiGŻPIB (PW 2011-2014). Warszawa, 26.

Zegar, J. (2014). Konkurencyjność rolnictwa zrównoważonego. Synteza (Competitiveness of sustainable agriculture. Synthesis). Monografie PW IERiGŻ-PIB, Warszawa,142.1.

Zagrożenia dla sektora trzody chlewnej ze strony ASF. Propozycja Projektu Planu Zwalczania Afrykańskiego pomoru Świń w Polsce (Threats to the pig sector on the part of ASF) (2015). Wyd. PZHiPTCh „Polsus”, Warszawa. Pobrano 11 kwietnia 2017 r. z: http://polsus.pl/images/photos/Wydawnictwa/ASF/ASF.pdf.

Zwierzęta gospodarskie w 2014 ...2016 roku (Farm animals in 2014 ...2016). (2015-2017). Wyd. GUS, Warszawa.

\section{Do cytowania / For citation:}

Kopiński J. (2018). Ocena zmian organizacyjno-produkcyjnych w polskim rolnictwie w kontekście wybranych oddziaływań środowiskowych. Problemy Rolnictwa Światowego, 18(4), 284-294; DOI: 10.22630/PRS.2018.18.4.118

Kopiński J. (2018). Assessment of Organizational and Production Changes in Polish Agriculture in the Context of Selected Environmental Impacts (in Polish). Problems of World Agriculture, 18(4), 284-294; DOI: 10.22630/PRS.2018.18.4.118 